\title{
Distribution of Uterin Cervical Lesions and Relation Between Age and Parity Rates in the Mardin Province
}

\author{
Mardin İlinde Uterin Servikal Lezyonların Dağılımı ve Yaş ve Doğum \\ Sayısı ile îlişkisi
}

\author{
Gonca ÖZGÜN', Gülay AYDOĞDU² \\ Department of Pathology, 'Uludağ University, Faculty of Medicine, BURSA, TURKEY, ${ }^{2}$ istanbul University, Istanbul Faculty of Medicine, Cytopathology,
} ISTANBUL, TURKEY

\begin{abstract}
Objective: The aim of this study is to evaluate the incidence and distribution of cervical lesions and compare characteristics such as parity and age of the women in Mardin province.
\end{abstract}

Material and Method: Pap smears were drawn from the women screened at Mardin Gynecology and Pediatric Diseases Hospital from 2008 to 2011. All cervicovaginal smears were conventional Pap smear samples evaluated according to the 2001 Bethesda system.

Results: There were 3.332 patients in total, whose smears showed no lesions in 3.125 patients. The mean age and number of parities of those patients were $37.34 \pm 11.25$ and $4.78 \pm 3.28$. There were 207 smears showing any lesions in cervix; ASC-US, ASC-H, LSIL, HSIL, AGC, squamous cell carcinoma and endocervical adenocarcinoma in 151 (72.94\%); 16 (7.72\%); 20 (9.66\%); 8 (3.86\%); 10 (4.83\%); 1 (0.48\%) and $1(0.48 \%)$ patient, respectively. The mean age and the parities of the patients were $37.63 \pm 10.77$ years and $4,74 \pm 2,92$. Although there was no difference between the control and lesion groups, the parity and the age of patients who had $\geq 4$ births in both the control and lesion groups were significantly higher than the patients with parities $<4$ births $(\mathrm{p}=0.000)$. There was no difference within the cervical lesion group comparing the ASC-US group with the total of the other lesions.

Conclusion: High parity was one of the risk factor for having a lesion in uterine cervix in this population. This study represents an initial attempt to reflect the prevalence and the distribution of cervical lesions and their relation with the parity rates in the eastern regions in Turkey.

Key Words: ASC-US, Cervix dysplasia, Multiparity, Mardin
ÖZ

Amaç: Bu çalışmanın amacı, Mardin ilinde servikal displazi ve servikal kanser insidansını ve kadınların doğum sayısı ve yaşı ile ilişkisini araştırmaktır.

Gereç ve Yöntem: 2008 Mayıs ile 2011 Şubat ayları arasında Mardin Kadın Doğum ve Çocuk Hastalıkları Hastanesine gelen hastalardan alınan konvansiyonel smear örnekleri, Papanicolaou (Pap) boyası ile boyandı ve Bethesda 2001 sistemi kriterlerine göre değerlendirildi.

Bulgular: Toplam 3.332 hastanın smear örnekleri incelendi. Hastaların 3.125'inde herhangi bir lezyon saptanmazken, 207 hastanın smear sonuçları ASC-US (151 hasta; \%72,94), ASC-H (16 hasta; \%7,72), L-SIL (20 hasta; \%9,66), H-SIL (8 hasta; \%3,86), AGC (10 hasta; \%4,83), skuamöz hücreli karsinom (1 hasta; \%0,48) ve endoservikal adenokarsinom ( 1 hasta; \%0,48) olarak tanı aldı. Herhangi bir lezyonu olmayan 3125 hastalık kontrol grubunun yaş ortalaması $37,34 \pm 11,25$ ve doğum sayısı ortalamas $4,78 \pm 3,28$ olarak saptanırken, smear örneğinde herhangi bir lezyon tanısı alan 207 hastanın yaş ortalaması $37,63 \pm 10,77$ ve doğum sayısı ortalaması $4,74 \pm 2,92$ bulundu. Kontrol grubu ile lezyon grubu arasinda bu değişkenler açısından fark bulunmazken, hem kontrol grubunda hem servikal lezyon grubunda, ortalama doğum sayıları ve ortalama yaşlar, doğum sayısı $\geq 4$ olan hasta grubunda, doğum sayısı $<4$ olan gruptan yüksek bulundu $(\mathrm{p}=0,000)$. Servikal lezyon grubu kendi içinde değerlendirildiğinde ise, ASC-US ve diğer lezyonlar arasında parite ve yaş açısından fark saptanmadi.

Sonuç: Yüksek doğum sayısı, uterin servikste herhangi bir lezyon varlığı açısından değerlendirildiğinde risk faktörlerinden biri olarak karşımıza çıkmaktadır. Bu çalışma, Türkiye'nin doğu illerindeki servikal lezyonların insidansı ve dağılımı ile doğum sayıları arasındaki ilişkiyi yansıtmak için bir başlangıç olabilir.

Anahtar Sözcükler: ASC-US, Serviks displazisi, Multiparite, Mardin
(Turk Patoloji Derg 2013, 29:46-50)

Received : 01.11.2012 Accepted : 03.12.2012
Correspondence: Gonca ÖZGÜN

Department of Pathology, Uludağ University, Faculty of Medicine, BURSA, TURKEY

E-mail: goncabarit@hotmail.com Phone: +90 2242953680 


\section{INTRODUCTION}

Cervical cancer accounts for $15 \%$ of all cancers in women and is the second most common cancer affecting women worldwide. Almost $85 \%$ of these cases occur in low-income countries (1).

It is well known that population-based cervical cancer screening using the Papanicolaou (Pap) test makes the early diagnosis of cervical cancer possible. The role of high risk Human Papilloma Virus (HPV) in the progression of cervical intraepithelial neoplasia to malignancy is well demonstrated. There are also many other aetiological factors that might contribute to the development of cervical carcinoma. These are high age and high parity, early age at first sexual intercourse, having multiple sex partners and smoking (2). Cervical cancer is the ninth most common cancer among women in Turkey and ranks 13th among cancer related deaths. More than $50 \%$ of the 1.364 patients diagnosed with cervical cancer each year in Turkey die of the disease (3).

Although national screening programs have been initiated by the Ministry of Health, information about the incidence of cervical cancer by province does not exist. The aim of the present study was to evaluate the prevalence of cervical cytological abnormalities and the association with parity.

\section{MATERIAL and METHODS}

A total of 5.984 Pap smears were obtained from the women screened at Mardin Gynecology and Pediatric Diseases Hospital from May2008 to February2011. All cervicovaginal smears were conventional Pap smear samples evaluated by two different pathologists at the Pathology unit according to the 2001 Bethesda system criteria. The Pap smear results were re-assessed and the information about parity was also accessed from the archives. Those where information about parity was not available were excluded from the study. Thus the study was eventually carried out with 3.332 patients. The records of all patients with a diagnosis of atypical squamous cells with undetermined significance (ASC-US), atypical squamous cells cannot exclude high-grade squamous intraepithelial lesion (H-SIL) (ASC-H), atypical glandular cells (AGC), low-grade squamous intraepithelial lesion (L-SIL), squamous cell carcinoma or adenocarcinoma were reviewed for numbers of parity and patients' ages.

Statistical analysis was performed with the SPSS statistical software for Windows, version 13.0 (SPSS Inc, Chicago, IL, USA). Continuous variables were expressed with mean $\pm S D$, median, maximum-minimum. The normality of data for continuous variables (age and parity) was checked using the Kolmogorov-Smirnov test before the statistical analysis was performed. Differences between groups were analyzed using the Student T-test for continuous variables. A $P$ value of 0.05 was considered to be statistically significant.

\section{RESULTS}

The total number of re-evaluated smears was 3.332. The medical records of all patients were reviewed for numbers of parity and age. There were 3.125 smears which showed no lesions, accepted as the control group. The mean age of those patients was $37,34 \pm 11,25$ (median: 36 ; min: 14 , max: 82 ) years and the mean number of parities was $4.78 \pm 3.28$ (median: 4; min: 0, max: 20). There were 207 smears showing any lesion. The distribution of the diagnoses of the smears was listed as: ASC-US in 151 (72.94\%); ASC-H in $16(7.72 \%)$; L-SIL in 20 (9.66\%); H-SILs in 8 (3.86\%); AGC in $10(4.83 \%)$. The prevalence of invasive cervical neoplasia was $0.06 \%$. There was squamous cell carcinoma in 1 patient $(0.48 \%)$ and endocervical adenocarcinoma in 1 patient $(0.48 \%)$. The mean age of the 207 patients was $37.63 \pm 10.77$ (median: 37; min: 18, max: 78) years and mean number of parities was $4.74 \pm 2.92$ (median: 4; min: 0, max: 17). There were no differences between the control group and cervical lesion group by age and the number of parities (Table I).

In the control group, there were 1,811 patients who had $\geq 4$ births, and 1.314 patients who had $<4$ births. The mean age and parities of the patients who had $\geq 4$ births were $41.86 \pm 10.64$ (median: 41; min: 16 , max: 82 ) years and 6.88 \pm 2.71 (median: 6; min: 4, max: 20 ). The mean age and parities of the 1,314 patients who had $<4$ births were $31.10 \pm 8.83$ (median: 29,5; min: 14, max: 79 ) years and $1.88 \pm 0.98$ (median: 2 ; min: 0 , max: 3 ). In the cervical lesion group, there were 128 patients who had $\geq 4$ births, and 79 patients who had $<4$ births. The mean age and parities of the patients who had $\geq 4$ births were $41.05 \pm 10.61$ (median: 40; min: 21, max: 77) years and 6.39 \pm 2.49 (median: 6; min: 4, max: 17). The mean age and parities of the 79 patients who had $<4$ births were $32.09 \pm 8.55$ (median: 31 ; min: 17 , max: 60) years and 2.08 \pm 0.87 (median: 2; min: 0, max: 3 ). In both the control group and the cervical lesion group, the mean parity numbers and the ages of patients who had $\geq 4$ births was significantly higher than the patients who had $<4$ births ( $\mathrm{p}=0.000 ; 0.000 ; 0.000$ and 0.000 , respectively) (Table II).

There was no statistically significant difference in the lesion group itself when comparing the ASC-US group with the total of the other lesions (LSIL, HSIL, ASC-H, AGC, SCC and adenocarcinoma) (Table III). 
Table I: Comparison of the control group and the cervical lesion group according to the number of parity and age

\begin{tabular}{|l|c|c|c|}
\hline & Control group (3.125) & Lesion group (207) & p \\
\hline Parity $_{\text {mean }}$ (median) & $\begin{array}{c}4,78 \pm 3,28 \\
(4 ; \text { min:0-max:20) }\end{array}$ & $\begin{array}{c}4,74 \pm 2,92 \\
(4 ; \text { min:0-max:17) }\end{array}$ & 0,893 \\
\hline Age $_{\text {mean }}$ (median) & $\begin{array}{c}37,34 \pm 11,25 \\
(36 ; \text { min:14-max: } 82)\end{array}$ & $\begin{array}{c}37,63 \pm 10,77 \\
(37 ; \text { min:18-max:78) }\end{array}$ & 0,717 \\
\hline
\end{tabular}

Table II: Comparison of the groups according to the number of parities in themselves

\begin{tabular}{|c|c|c|c|}
\hline Control group (3.125) & Parity $\geq 4(1.811)$ & Parity $<4(1.314)$ & $\mathbf{p}$ \\
\hline Parity $_{\text {mean }}$ (median) & $\begin{array}{c}6,88 \pm 2,71 \\
\text { (6; min:4-max:20) }\end{array}$ & $\begin{array}{c}1,88 \pm 0,98 \\
(2 ; \min : 0-\max : 3)\end{array}$ & 0,000 \\
\hline $\mathrm{Age}_{\text {mean }}$ (median) & $\begin{array}{c}41,86 \pm 10,64 \\
(41 ; \min : 16-\max : 82)\end{array}$ & $\begin{array}{c}31,10 \pm 8,83 \\
(29,5 ; \min : 14-\max : 79)\end{array}$ & 0,000 \\
\hline Lesion group (207) & Parity $\geq 4$ (128) & Parity <4 (79) & $\mathbf{p}$ \\
\hline Parity $_{\text {mean }}$ (median) & $\begin{array}{c}6,39 \pm 2,49 \\
\text { (6; min:4-max:17) }\end{array}$ & $\begin{array}{c}2,08 \pm 0,87 \\
(2 ; \min : 0-\max : 3)\end{array}$ & 0,000 \\
\hline $\mathrm{Age}_{\text {mean }}$ (median) & $\begin{array}{c}41,05 \pm 10,61 \\
(40 ; \min : 21-\max : 77)\end{array}$ & $\begin{array}{c}32,09 \pm 8,55 \\
(31 ; \min : 17-\max : 60)\end{array}$ & 0,000 \\
\hline
\end{tabular}

Table III: Comparison of the cervical lesion group according to the number of parity and age in itself

\begin{tabular}{|c|c|c|c|}
\hline Lesion group & ASC-US (151) & Others (56) & p \\
\hline Parity $_{\text {mean }}$ & $4,68 \pm 2,98$ & $4,93 \pm 2,77$ & 0,581 \\
\hline Age $_{\text {mean }}$ & $37,10 \pm 10,39$ & $39,05 \pm 11,72$ & 0,248 \\
\hline
\end{tabular}

\section{DISCUSSION}

The incidence and mortality rates of cervical cancer have decreased dramatically in many European countries since the introduction of the Pap test in the early 1940s and the ensuing implementation of national screening programs. Despite false-negative rates between $6 \%$ and $50 \%$, this test is still considered the most effective to detect precancerous lesions (4). The 2001 Bethesda System for reporting cervical or vaginal cytologic diagnoses is an incremental change in the uniform terminology introduced in 1988 and revised in 1991 (5). The existing screening programs have decreased the prevalence of cervical carcinoma, which used to be one of the leading causes of death among women. In Turkey, local health programs of Ministry of Health and an increased awareness in the community have lowered the prevalence of cervical carcinomas from the seventh cause of death for women in 1996 to the eighth in 2006 (6).

A variety of possible cofactors have been identified with varying degrees of consistency that could act either before or after the development of in situ disease. These include the followings: early age at first sexual intercourse, which may reflect particular vulnerability of the immature cervix to HPV-induced carcinogenesis, hormonal factors such as high parity and use of oral contraceptives, exposures to chemical agents in cigarette smoke, sexually transmitted agents (HPV and others), an immunocompromised state resulting from human immunodeficiency virus (HIV) infection or immunosuppression for prevention of organ transplant rejection, and various measures of socioeconomic status, suggesting the presence of additional unrecognized cofactors associated with social class (7).

Cervical cancer also seems to be associated with continued multiple damages and injuries. This type of cancer is more frequent in women in low socioeconomic groups and is connected with engaging in first coitus at early ages and having multiple sexual partners (8). The population of Mardin province, the city center and related villages, is 744,606 (9). It is a city in the south-east region and rates of parity are higher than other provinces which are located in western regions of Turkey. Considering the ages at first 
marriage and first sexual intercourse, which are lower in eastern regions of Turkey, and the habit of getting fellow wives, which is still widely accepted in the rural population of the eastern and southeastern regions of Turkey, we can say that the socioeconomic status and the awareness of cervical health in women are lower than the other regions.

The prevalence of ASC-US, L-SIL, H-SIL, and AGC in the USA has been reported as $3.9 \%, 2.1 \%, 0.5 \%$, and $0.2 \%$, respectively (10). In the present study the overall prevalence of cytological abnormality was $6.21 \%$ and the prevalence of ASC-US, L-SIL, H-SIL, and AGC was 5.53\%, 0.60\%, 0.24\%, and $0.30 \%$, respectively. It is well known that the prevalence of preinvasive and invasive abnormal cervical cytology varies according to patient population, diagnostic criteria utilized, and the experience and skill of the cytologist and pathologist. The prevalence of abnormal cervical cytology in the present study was different from and approximately 4 times higher (1.8\%) than in those previously reported from the western regions of Turkey (3). In another study from the Şanliurfa province, which is in the southeast region and the worst city of Turkey in socioeconomic conditions according to the State Institute of Statistics, 9,079 smears were taken and ASC-US was detected in $1.6 \%$ of the cases, ASC-H in $0.06 \%$ of the cases, L-SIL in $0.07 \%$ of the cases, $\mathrm{H}$-SIL in $0.02 \%$ of the cases, AGC in $0.05 \%$ of the cases, and SCC in only in one patient which was determined to be $0.01 \%(8)$.

Genital HPV infection is the most common sexually transmitted viral infection worldwide. It is associated with various clinical conditions, ranging from asymptomatic infections to benign and malignant diseases, which include genital warts, cervical intraepithelial neoplasia and invasive cervical cancer (11). It has been clearly demonstrated with planned follow-up of L-SIL cases that these precancerous lesions persist longer and progress more quickly in women with oncogenic HPV infection than in women with nononcogenic infection or no HPV infection (12).

In a study from Gaziantep province, which is one of the biggest cities in the southeast region of Turkey, the prevalence and genotype distribution were studied. HPV DNA was positive in $16.9 \%$ of the women overall and in $15.1 \%$ of women with normal cervical cytology as the rates in newer studies from Turkey $(13,14)$. The most common genotypes in HPV infected women were HPV 18 and HPV 16 , which are also the most commonly detected types worldwide. Other common types were HPV 54, 6, 58 and 59 among the female population in Gaziantep province. According to that study, there was a significant association between abnormal cervical cytology and having cervical erosion regardless of HPV infection (13). We had been working in that hospital while we served our compulsory services and the Pathology unit consisted of only a cytology laboratory. Unfortunately, there were no opportunities to compare the diagnosis between the smears and biopsies. Although there was no colposcope or HPV DNA testing in Mardin province, we had still written foot-notes about suggested colposcopic assessment for ASC-H, L-SIL, and $\mathrm{H}$-SIL within the final reports.

Parity was one of the earliest risk factors to be associated with cancer risk. Already in 1842, on the basis of death certificates in Verona, Italy, Rigoni-Stern observed that cancers of the uterus (which at that time chiefly originated from the cervix) were more frequent in married women, who tended to be multiparous (15). High parity was one of the risk factors for cervical cancer $(16,17)$. In another study the risk increased markedly with increasing parity and was over four-fold in women with four or more births, compared with women with under four births (17). Some case control studies have shown the association with parity for cervix carcinoma (18). The effect of parity in cervical cancer development seems to be mainly detectable in countries with high fertility rates and is rarely found in lowparity countries. Parity is probably a good marker of the oestrogen-hormonal environment throughout the fertile years of a woman as well as a marker of repeated cervical trauma among highly parous women. It is not known whether hormones intervene in cervical carcinogenesis but oestradiol has been reported to induce immortalization of HPV-infected cells (19). According to a study, high parity was associated with HPV infection but not with the risk of carcinoma of cervix (20). Comparing the cervical lesion group and the control group, our study indicated that the number of births did not have a role in the development of any cervical lesions. However, in the cervical lesion group, the mean number of parities in the patients who had $\geq 4$ births was higher than the patients who had $<4$ births. According to our study, the prospect of having a lesion in the cervix increases if a patient has 4 or more births.

Even though the present study has limitations and further prospective studies are needed, this could represent an initial attempt to reflect the prevalence and the distribution of cervical lesions in the eastern regions in Turkey.

\section{ACKNOWLEDGEMENTS}

The authors thank Dr. Serkan Yazıcı for assistance with aspects of the statistical analysis of the study. 


\section{REFERENCES}

1. Boyle P, Ferlay J: Cancer incidence and mortality in Europe, 2004. Ann Oncol 2005, 16:481-488

2. Rosai J: Ed. Rosai and Ackerman's Surgical Pathology. 9th ed., Elsevier, 2004, 1523-1569

3. Turkish Cervical Cancer and Cervical Cytology Research Group: Prevalence of cervical cytological abnormalities in Turkey. Int J Gynaecol Obstet 2009, 106:206-209

4. Karabulut A, Alan T, Ali Ekiz M, Iritas A, Kesen Z, Yahsi S: Evaluation of cervical screening results in a population at normal risk. Int J Gynaecol Obstet 2010, 110:40-42

5. Apgar BS, Zoschnick L, Wright TC, Jr: The 2001 Bethesda System terminology. Am Fam Physician 2003, 68:1992-1998

6. Türkiye Cumhuriyeti Sağlık Bakanlığı: 2004-2006 Yılları Türkiye Kanser İnsidansı. 2009 (updated 2009; cited); Available from: http://www.kanser.gov.tr/index.php?cat=11.

7. Thomas DB, Qin Q, Kuypers J, Kiviat N, Ashley RL, Koetsawang A, Ray RM, Koetsawang S: Human papillomaviruses and cervical cancer in Bangkok. II. Risk factors for in situ and invasive squamous cell cervical carcinomas. Am J Epidemiol 2001, 153:732-739

8. Özgül N: The state of cervical cancer in Turkey and Cervical cancer screening studies. In Tuncer, M. (Ed): Cancer Control in Turkey, Ankara, National Cancer Advisory Board of Turkey, 2008, 347-356

9. T.C.Mardin Valiligi: T.C.Mardin Valiligi. 2010 [updated 2010; cited 2010]; Available from: http://www.mardin.gov.tr/web/ mardinvaliligi/detay.asp?id=127\&kategori=MARDİN .

10. Davey DD, Neal MH, Wilbur DC, Colgan TJ, Styer PE, Mody DR: Bethesda 2001 implementation and reporting rates: 2003 practices of participants in the College of American Pathologists Interlaboratory Comparison Program in Cervicovaginal Cytology. Arch Pathol Lab Med 2004, 128:1224-1229

11. Baseman JG, Koutsky LA: The epidemiology of human papillomavirus infections. J Clin Virol 2005, 32:16-24
12. Schlecht NF, Duarte-Franco E: Human Papillomavirus infection and time to progression and regression of cervical intraepithelial neoplasia. J Natl Cancer Inst 2003, 95:1336-1343

13. Bayram A, Erkılıç S: Prevalence and genotype distribution of HPV in nonneoplastic cervical tissue lesion: Cervical erosion. J Med Virol 2011, 83:1997-2003

14. Inal MM, Kose S, Yildirim Y, Ozdemir Y, Töz E, Ertopçu K, Ozelmas I, Tinar S: The relationship between human papilloma virus infection and cervical intraepithelial neoplasia in Turkish women. Int J Gynecol Cancer 2007, 17:1266-1270

15. International Colloboration of Epidemiological Studies of Cervical Cancer: Cervical carcinoma and reproductive factors: Collaborative reanalysis of individual data on 16,563 women with cervical carcinoma and 33,542 women without cervical carcinoma from 25 epidemiological studies. Int J Cancer 2006, 119:1108-1124

16. Brinton LA, Reeves WC, Brenes MM, Herrero R, de Britton RC, Gaitan E, Tenorio F, Garcia M, Rawls WE: Parity as a risk factor for cervical cancer. Am J Epidemiol 1989, 130:486-496

17. Bayo S, Bosch FX, de Sanjose S, Munoz N, Combita AL, Coursaget P, Diaz M, Dolo A, van den Brule AJ, Meijer CJ: Risk factors of invasive cervical cancer in Mali. Int J Epidemiol 2002, 31:202-209

18. Altekruse SF, Lacey JVJ, Brinton LA, Gravitt PE, Silverberg SG, Barnes WAJ, Greenberg MD, Hadjimichael OC, McGowan L, Mortel R, Schwartz PE, Hildesheim A: Comparison of human papillomavirus genotypes, sexual, and reproductive risk factors of cervical adenocarcinoma and squamous cell carcinoma: Northeastern United States. Am J Obstet Gynecol 2003, 188:657-663

19. Parazzini F, La Vecchia C, Negri E, Cecchetti G, Fedele L: Reproductive factors and the risk of invasive and intraepithelial cervical neoplasia. Br J Cancer 1989, 59:805-809

20. Yetimalar H, Kasap B, Cukurova K, Yildiz A, Keklik A, Soylu $F$ : Cofactors in human papillomavirus infection and cervical carcinogenesis. Arch Gynecol Obstet 2012, 285:805-810 